\title{
Analisis Beberapa Faktor yang Berpengaruh terhadap Penggunaan Informasi Akuntansi pada Usaha Kecil dan Menengah
}

\author{
Seftianita Nirmalasari \\ Universitas Wijaya Kusuma Surabaya, seftiana.virgo@gmail.com
}

http://

\begin{abstract}
Abstrak
Small and medium enterprises are the largest economic community in Indonesia and are one of the factors of economic growth after the economic crisis. In addition, small and mediumsized businesses open up quite large job opportunities. Accounting information is one of the important things for the development of small and medium enterprises. Soo this research the writer wants to analyze more clearly about several factors that influence the use of accounting information in small and medium enterprises in the of Pudak city Gresik. The population in this study were the owners / managers of small and medium enterprises in the of Pudak city Gresik. The number of samples studied was 86 respondents. Sampling using random sampling technique. The data analysis used multiple linear regression analysis with the help of the SPSS program. The results of data analysis show that business scale, business age, accounting knowledge, and accounting training are found to have a positive and significant effect on the use of accounting information in small and medium enterprises in the of Pudak city Gresik.
\end{abstract}

Keywords : Business Scale, Business Age, Knowledge, Training, Accounting Information.

\section{Pendahuluan}

Usaha kecil dan menengah (UKM) adalah komunitas ekonomi terbesar di Indonesia dan merupakan salah satu faktor pertumbuhan ekonomi setelah terjadinya krisis ekonomi, disamping itu UKM membuka peluang kerja yang cukup besar (Setyawati dan Hermawan. 2018). UKM diharapkan dapat meningkatkan perekonomian Indonesia saat ini, mengingat bahwa sebagian besar bisnis yang ada di Indonesia adalah UKM. Usaha kecil dan menengah masih mendominasi perekonomian di berbagai negara, khususnya di Indonesia. Pengembangan UKM belakangan ini telah menjadi usaha kuliner rumahan yang sangat pesat dan berkembang pesat dengan kemajuan yang dilakukan oleh ibu rumah tangga dan kaum muda (milenial), selain bisnis kuliner terdapat juga bisnis lain seperti desain kaos, desain etnik, desain batik, desain sablon dan bisnis sepatu juga menjadi tren saat ini.

Usaha kecil dan menengah (UKM) sebagian besar menganggap bahwa melakukan pencatatan transaksi tidak terlalu penting untuk diterapkan. Kurangnya pengetahuan bisnis juga sering tidak disertai dengan pemenuhan sumber daya untuk menjalankan usaha (Sari, 2011). Banyak pelaku bisnis, khususnya UKM, belum memahami pentingnya pencatatan transaksi untuk kelangsungan usaha. Sari (2011) menjelaskan bahwa kesadaran akan pentingnya pencatatan transaksi sering muncul ketika pelaku bisnis harus berurusan dengan lembaga atau pihak lain yang memerlukan laporan keuangan bisnis untuk kegiatan tertentu. 
Menurut (Kurniawati et al., 2012; Setiyawati \& Hermawan, 2018) menjelaskan bahwa masih ada kurangnya kesadaran tentang pentingnya pencatatan transaksi di UKM. Menunjukkan bahwa UKM telah melaksanakan catatan transaksi yang sederhana. Sedang (Kurniawati et al., 2012) juga meneliti bagaimana UKM memperoleh informasi akuntansi dari catatan transaksi dan menggunakan informasi tersebut dalam proses pengambilan keputusan bisnis. Wahyudi (2009) menunjukkan bahwa skala pendidikan dan bisnis mempengaruhi penggunaan informasi akuntansi UKM. Tapi, usia perusahaan dan pelatihan akuntansi sebenarnya tidak berpengaruh pada penggunaan informasi akuntansi di UKM. Mubarok (2011) juga menunjukkan bahwa skala pendidikan dan bisnis tidak berpengaruh baik sebagian atau bersamaan pada penggunaan informasi akuntansi.

Sari (2013) menunjukkan bahwa secara simultan terdapat efek yang signifikan antara pendidikan, skala bisnis, usia bisnis dan pelatihan akuntansi yang diikuti oleh pemilik UKM terhadap tindakan penyediaan dan penggunaan informasi akuntansi untuk UKM. Sedangkan, (Novianti et al., 2018) menunjukkan bahwa pendidikan dan pelatihan akuntansi yang sebagian diikuti oleh pemilik bisnis memiliki dampak positif pada penggunaan informasi akuntansi. Namun, usia dan skala bisnis perusahaan tidak berpengaruh pada penggunaan informasi akuntansi.

Skala bisnis adalah skala yang dapat diklasifikasikan sesuai dengan ukuran perusahaan. Ukuran perusahaan dapat dilihat dari jumlah aset, jumlah karyawan dan jumlah pendapatan yang diterima oleh perusahaan dalam periode Akuntansi (Holmes dan Nicholls, 1988). Skala bisnis yang lebih besar diharapkan dapat mendorong seseorang untuk menggunakan informasi akuntansi untuk keberlanjutan bisnis mereka. Hasil penelitian dari Murniati (2002), Wahyudi (2009), dan Ratnasari (2014) menemukan bahwa skala usaha memiliki dampak positif pada penggunaan informasi akuntansi, sedangkan Widiyanti (2013) dan Hariyadi (2013) menemukan bahwa skala usaha tidak berpengaruh pada penggunaan informasi akuntansi.

Menurut (Tuti \& Dwijayanti, 2015) menyatakan bahwa usia bisnis adalah lama perusahaan beroperasi yang menunjukkan bahwa perusahaan tersebut ada dan mampu bersaing di pasar sehingga dapat mempertahankan bisnisnya dan mencapai tujuan yang diinginkan. Biasanya bisnis yang sudah lama berdiri cenderung lebih berkembang karena sudah memiliki banyak pengalaman dalam menjalankan bisnis. Semakin lama perusahaan beroperasi, kebutuhan untuk informasi akuntansi akan lebih kompleks. Hasil penelitian dari Setyowati (2011), Aufar (2013), dan Budiarta (2016), menemukan bahwa usia bisnis memiliki efek positif pada penggunaan informasi akuntansi, sedangkan Wahyudi (2009) dan Ratnasari (2014) menemukan bahwa usia bisnis tidak berpengaruh pada penggunaan informasi akuntansi.

Hasil penelitian Fitriyah (2006) menunjukkan bahwa pengetahuan akuntansi memiliki efek positif pada penggunaan informasi akuntansi dan menjelaskan bahwa pengetahuan Akuntansi sangat dibutuhkan oleh pemilik perusahaan dalam melaksanakan operasi perusahaan. Sejalan dengan Fitriyah (2006), hasil penelitian dari Setyaningrum dan Sukirman (2014) menunjukkan bahwa pengetahuan akuntansi memiliki efek positif pada penggunaan informasi akuntansi di MSMEs. Berbeda dengan hasil penelitian Wahyudi (2009) yang menunjukkan bahwa pengetahuan akuntansi tidak berpengaruh pada penggunaan informasi akuntansi.

Hasil penelitian (Astuti, 2007) Anugrah (2003), Astuti (2007), dan Andriani dan Zuliyati (2015) menemukan bahwa pelatihan akuntansi memiliki efek positif pada penggunaan informasi akuntansi. Berbeda dengan hasil penelitian yang dilakukan Wahyudi (2009), dan Ratnasari (2014) yang menjelaskan bahwa pelatihan akuntansi tidak berpengaruh pada penggunaan informasi akuntansi.

Penelitian ini adalah pengembangan dari penelitian-penelitian sebelumnya, dan mengadopsi beberapa variabel penelitian diantaranya masa memimpin pemilik/manajer, omzet perusahaan, tingkat pendidikan pemilik/manajer, pelatihan akuntansi yang diikuti pemilik/manajer, dan skala usaha. Perusahaan kecil dan menengah yang memiliki yang berlokasi di kota Pudak Gresik merupakan objek dalam penelitian ini, dengan tujuan untuk memperkecil kemungkinan variabel lain yang dapat berpengaruh terhadap penggunaan informasi akuntansi. Agar dapat memberikan hasil yang signifikan.

Kabupaten Gresik yang merupakan sub wilayah pengembangan bagian (SWPB) tidak terlepas dari kegiatan sub wilayah pengembangan Gerbang Kertasusila (Gresik, Bangkalan, 
Surabaya, Sidoarjo, Lamongan) yang pada hal ini adalah termasuk salah satu bagian dari 9 sub wilayah pengembangan jawa timur yang kegiatannya diarahkan pada sektor pertanian, industri, perdagangan, maritime, pendidikan dan industri wisata. Berdasarkan data Dinas Kependudukan dan Pencatatan Sipil Kabupaten Gresik jumlah penduduk Kabupaten Gresik pada akhir tahun 2017 sebanyak 1,313,826 jiwa yang terdiri dari 661,145 laki-laki dan 652,681 perempuan. Jumlah tersebut berada pada 383,463 keluarga. Dengan luas wilayah $1.191,25 \mathrm{~km} 2$ Kabupaten Gresik mempunyai Kepadatan penduduk pada tahun 2017 sebesar $1,103 \mathrm{jiwa} / \mathrm{Km} 2$. Berdasarkan data dari pemerintah kota Gresik saat ini terdapat 132 usaha kecil dan menengah yang telah terdaftar secara resmi di Kabupaten Gresik dengan latar belakang industri yang beragam mulai dari kerajinan, pakaian batik, sepatu, makanan, dan lain sebagainya.

Menyadari pentingnya peran usaha kecil dan menengah di kota Gresik bagi perekonomian serta pentingnya informasi akuntasi bagi perkembangan UKM, maka salah satu faktor yang menjadi penghambat kurang berkembangnya UKM di Indonesia adalah rendahnya penggunaan informasi akuntasi pada UKM di Indonesia oleh sebab itu penelitian ini sangat menarik untuk diteliti lebih lanjut yaitu untuk menganalisis apakah skala usaha, usia bisnis, pengetahuan akuntansi dan pelatihan akuntansi berpengaruhaterhadap penggunaan informasi akuntansi pada UKM di Kota Pudak Gresik. Penelitian ini diharapkan dapat dijadikan sebagai referensi guna menambah pengetahuan dalam bidang informasi akuntansi pada UKM serta menjadi pendorong untuk dilakukannya penelitian selanjutnya tentang informasi akuntansi yang berguna bagi UKM.

\section{Telaah Literatur dan Pengembangan Hipotesis}

\subsection{Landasan Teori}

\subsubsection{Skala Usaha}

Skala usaha menurut Holmes dan Nicholls (1988) yaitu kemampuan perusahaan dalam mengelola usaha dengan memerhatikan besarnya aset, jumlah karyawan, dan pendapatan yang diperoleh selama satu periode akuntansi. Skala usaha merupakan salah satu indikasi perkembangan suatu perusahaan dimana perusahaan yang besar akan membawa dampak bagi karyawan yang terlibat didalamnya. Bertambahnya karyawan dari tahun ketahun menandakan perusahaan tumbuh dan berkembang dikarenakan perusahaan yang besar akan membutuhkan karyawan dengan jumlah yang besar pula. Jika skala usaha meningkat, maka proporsi perusahaan dalam menyediakan informasi akuntansi, dan informasi tambahan juga meningkat (Meliana dan Dewi, 2015). Penggunaan informasi akuntansi akan sangat membantu dalam mengelola kompleksitas suatu perusahaan.

\subsubsection{Usia bisnis}

Usia bisnis adalah usia atau jangka waktu perusahaan beroperasi (Linear Diah Sitoresmi, 2013) usia perusahaan menghasilkan perubahan pola pikir dan tingkat kemampuan pemilik bisnis dalam membuat keputusan untuk masing-masing tindakannya. Pemilik bisnis yang telah lama mengoperasikan bisnis mereka telah belajar lebih banyak dari pengalaman mereka daripada mereka yang baru saja mulai mengoperasikan bisnis mereka. Usia bisnis dalam studi ini diukur berdasarkan lamanya waktu operasi bisnis (dalam tahun) yang dihitung dari awal pendirian bisnis sampai penelitian ini dilakukan.

\subsubsection{Pengetahuan Akuntansi}

Pengetahuan adalah informasi yang diperoleh oleh seseorang tentang sesuatu yang diperoleh melalui belajar, memahami dan mengalami (Bestianti, 2015). Pengetahuan terdiri dari 3 domain, yaitu kognitif, afektif, dan psikomotor. Pertama, dari perspektif kognitif, akuntansi pengetahuan adalah kemampuan seseorang untuk mengenali akuntansi sebagai proses pencatatan, pengelompokan, dan meringkas peristiwa ekonomi (Belkaoui, 2011). Kedua, afektif domain dari pengetahuan akuntansi menunjukkan sikap kesadaran tentang pentingnya peran akuntansi untuk pengguna (Djazari dan Sagoro, 2011) dan ketiga, domain psikomotor 
dilihat dari kemampuan untuk menyortir dan mencatat bukti transaksi, serta untuk menyelesaikan masalah yang terjadi (AFFF, 2014).

\subsubsection{Pelatihan Akuntansi}

Pelatihan akuntansi yang dimaksud dalam studi ini adalah jumlah atau frekuensi pelatihan di yang diselenggarakan oleh lembaga pendidikan non-sekolah atau perguruan tinggi, Pusat kantor pemerintah yang dihadiri oleh pemilik UKM (Novianti et al., 2018). Pelatihan akuntansi yang dihadiri oleh pemilik UKM akan diukur berdasarkan frekuensi pelatihan akuntansi yang dihadiri.

\subsubsection{Informasi Akuntasi}

Informasi akuntansi adalah data mentah transaksi yang telah berubah menjadi angka keuangan, yang digunakan untuk membuat keputusan ekonomi (Jones et al., 1996). Untuk usaha kecil, akuntansi sering digambarkan sebagai proses yang sangat sederhana dari pencatatan transaksi dan pelaporan keuangan, yang dikenal sebagai pembukuan (karyawati, 2008). Penerapan Akuntansi di UKM tergantung pada pengetahuan pelaku bisnis, yang mempengaruhi proses akuntansi yang digunakan dalam menghasilkan informasi (Lestanti, 2015). Dalam hal ini, informasi akuntansi yang digunakan dalam studi berasal dari proses perekaman transaksi.

\subsubsection{Usaha Kecil dan Menengah (UKM)}

Menurut Undang-Undang No. 20 Tahun 2008 tentang Usaha Kecil, dan Menengah: "Usaha kecil adalah usaha ekonomi produktif yang berdiri sendiri, yang dilakukan oleh orang perorangan atau badan usaha yang bukan merupakan anak perusahaan atau bukan cabang perusahaan yang dimiliki, dikuasai, atau menjadi bagian baik langsung maupun tidak langsung dari usaha menengah atau usaha besar yang memenuhi kriteria usaha kecil. Usaha menengah adalah usaha ekonomi produktif yang berdiri sendiri, yang dilakukan oleh orang perorangan atau badan usaha yang bukan merupakan anak perusahaan atau cabang perusahaan yang dimiliki, dikuasai, atau menjadi bagian baik langsung maupun tidak langsung dengan usaha kecil atau usaha besar dengan jumlah kekayaan bersih atau hasil penjualan tahunan. Berdasarkan definisi UKM menurut UU No. 20 Tahun 2008, usaha yang dimiliki oleh perorangan maupun badan usaha akan diklasifikasikan berdasarkan kriteriakriteria tertentu untuk mengetahui peningkatan perkembangan usaha dan terkait dengan UKM lebih berfokus untuk menghasilkan produk berdasarkan jenis usahanya.

Menurut Undang-Undang No. 20 Tahun 2008 Bab IV Pasal 6 mengenai kriteria UKM yaitu:

1. Usaha Kecil yang memiliki kekayaan bersih lebih dari Rp50.000.000,00 (lima puluh juta rupiah) sampai Rp500.000.000,00 (lima ratus juta rupiah) atau hasil penjualan tahunan yang didapatkan lebih dari Rp300.000.000,00 (tiga ratus juta rupiah) sampai $\mathrm{Rp} 2.500 .000 .000,00$ (dua milyar lima ratus juta rupiah).

2. Usaha Menengah yang memiliki kekayaan bersih lebih dari Rp500.000.000,00 (lima ratus juta rupiah) sampai Rp10.000.000.000,00 (sepuluh milyar rupiah) atau hasil penjualan tahunan yang didapatkan lebih dari Rp2.500.000.000,00 (dua milyar lima ratus juta rupiah) sampai Rp50.000.000.000,00 (lima puluh milyar rupiah).

\subsection{Pengembangan Hipotesis}

\subsubsection{Pengaruh Skala Usaha terhadap Penggunaan Informasi Akuntansi pada UKM}

Skala usaha adalah kemampuan suatu usaha untuk mengelola bisnisnya dengan melihat total aset, berapa banyak karyawan yang dipekerjakan dan berapa banyak pendapatan perusahaan yang dihasilkan dalam satu periode Akuntansi (Holmes dan Nicholls, 1988). Hasil studi yang dilakukan oleh Murniati (2002) menemukan bahwa skala bisnis memiliki dampak positif pada penggunaan informasi akuntansi di UKM. Ratnasari (2014) dan Hadi (2016) (Hadi et al., 2013) juga menemukan bahwa skala bisnis memiliki efek positif pada penggunaan informasi akuntansi di UKM. Peningkatan skala UKM dan proses bisnis yang lebih kompleks dari sebuah UKM membuat kebutuhan akuntansi yang sangat diperlukan untuk kelangsungan 
hidup sebuah UKM. Informasi akuntansi kemudian akan berguna untuk membuat keputusan manajerial untuk UKM. Dari hasil pemaparan diatas, diambil hipotesis untuk diuji lebih lanjut dalam penelitian ini, yaitu:

\section{$H_{1}: \quad$ Skala usaha berpengaruh positif terhadap penggunaan informasi akuntansi pada UKM.}

\subsubsection{Pengaruh Usia Bisnis terhadap Penggunaan Informasi Akuntansi pada UKM}

Usia bisnis dalam hal ini adalah lama operasi dari UKM atau usia dari UKM sejak bisnis ini didirikan. Semakin lama bisnis beroperasi, kebutuhan informasi akan lebih kompleks. Hasil penelitian oleh Kristian (2010) dan Hadi (2016) menemukan bahwa usia bisnis memiliki efek positif pada penggunaan informasi akuntansi di UKM. Budiarta (2016) juga menemukan usia bisnis memiliki efek positif pada penggunaan informasi akuntansi di UKM. Panjang bisnis yang berdiri membuat kebutuhan akuntansi untuk ummu, meningkatkan kesadaran pemilik UKM pentingnya akuntansi untuk terus mempertahankan bisnis mereka dan untuk tumbuh. Dari hasil pemaparan diatas, diambil hipotesis untuk diuji lebih lanjut dalam penelitian ini, yaitu:

\section{$\mathrm{H}_{2}$ : Usia bisnis berpengaruh positif terhadap penggunaan informasi akuntansi pada UKM.}

2.2.3 Pengaruh Pengetahuan Akuntansi terhadap Penggunaan Informasi Akuntansi pada UKM

Proses belajar tentang akuntansi akan meningkatkan pengetahuan akuntansi manajer/pemilik bisnis (pengusaha), sehingga pemahaman pengusaha (manajer) untuk menerapkan informasi akuntansi juga akan meningkat. Penelitian oleh Fitriyah (2006) dan Ismail dan King (2007) yang menunjukkan bahwa pengetahuan akuntansi pemilik/pengelola memiliki efek positif pada penerapan informasi akuntansi, yang artinya juga mempengaruhi persepsi pengusaha (manajer) informasi akuntansi. Penelitian Kiryanto, et al. (2001) dan Widiyanti (2013) juga mendukung hasil penelitian sebelumnya, menunjukkan bahwa pengetahuan akuntansi memiliki efek positif pada penggunaan informasi akuntansi keuangan. Dari hasil pemaparan diatas, diambil hipotesis untuk diuji lebih lanjut dalam penelitian ini, yaitu:

\section{$\mathrm{H}_{3}$ : Pengetahuan akuntansi berpengaruh positif terhadap penggunaan informasi akuntansi pada UKM.}

\subsubsection{Pengaruh Pelatihan Akuntansi terhadap Penggunaan Informasi Akuntansi pada UKM}

Pelatihan akuntansi adalah pelatihan dalam mengelola keuangan menggunakan akuntansi. Pelatihan akuntansi yang dimaksud adalah pelatihan akuntansi yang diselenggarakan oleh lembaga pendidikan non-sekolah atau lembaga pendidikan tinggi, atau pusat pelatihan. (Astuti, 2007; Linear Diah Sitoresmi, 2013) menemukan pelatihan akuntansi memiliki efek positif pada penggunaan informasi akuntansi di UKM. Andriani dan Zuliyati (2015) juga menemukan bahwa pelatihan akuntansi memiliki efek positif pada penggunaan informasi akuntansi di UKM. Pelatihan seputar akuntansi yang telah diikuti oleh manajer atau pemilik usaha dapat membuat praktek menggunakan akuntansi menjadi lebih besar, karena mereka tahu lebih banyak tentang pengetahuan akuntansi daripada manajer atau pemilik bisnis yang tidak pernah mengikuti pelatihan akuntansi. Dari hasil pemaparan diatas, diambil hipotesis untuk diuji lebih lanjut dalam penelitian ini, yaitu:

\section{$H_{4}$ : Pelatihan akuntansi berpengaruh positif terhadap penggunaan informasi akuntansi pada UKM.}

\section{Metode Penelitian}


Pendekatan penelitian ini menggunakan metode Kuantitatif dengan desain penelitian kausal, yaitu menggunakan analisis hubungan antara variabel yang satu dengan variabel yang lain atau menganalisis pengaruh variabel terhadap variabel lainnya. Penelitian ini menjelaskan hubungan antara skala usaha, usia bisnis, pengetahuan akuntansi, dan pelatihan akuntansi berpengaruh terhadap penggunaan informasi akuntansi pada UKM di kota Pudak Gresik. Penelitian ini merupakan penelitian hipotesis yang disertai pengujian statistik yang bertujuan untuk menguji hipotesis yang diduga sebelumnya. Penelitian ini dirancang berbentuk survei dilakukan dengan cara penyebaran kuisioner.

Populasi dalam penelitian ini adalah pemilik/manajer UKM yang berada di Kota Pudak Gresik. Pemilihan populasi ini berdasarkan wilayah dimana UKM tersebut menjalankan usahanya, sehingga dapat dijadikan responden untuk mengetahui penggunaan informasi akuntansi pada UKM. Dalam melakukan penelitian ini, peneliti menggunakan sampel untuk mengefisienkan waktu serta biaya, sehingga tidak semua UKM menjadi objek. Sampel adalah bagian yang mengandung karakteritistik populasi yang lebih besar (Saunders, et al., 2012). Teknik pengambilan sampel yang digunakan dalam penelitian ini adalah random sampling. Teknik random sampling melibatkan pemilihan sampel secara acak dari kerangka sampel menggunakan komputer atau tabel angka acak (Saunders, et al., 2012). Alasan penulis menggunakan teknik random sampling adalah agar dapat memberikan peluang yang sama bagi setiap anggota populasi untuk dipilih menjadi sampel. Menurut Roscoe dalam Sekaran dan Bougie (2017) menentukan ukuran sampel yang lebih besar dari 30 dan kurang dari 500 tepat untuk sebagian besar penelitian dan untuk penelitian multivariat (termasuk analisis regresi berganda). Sampel yang digunakan adalah pemilik/manajer UKM yang secara acak ditemui dalam berbagai wilayah di Kota Gresik.

Kategori variabel dalam penelitian ini dapat dikategorikan ke dalam 2 (dua) yaitu variabel dependen dan variabel independen. Variabel dependen merupakan variabel yang dipengaruhi oleh respon terhadap perubahan variabel lain. Variabel dependen dalam penelitian ini adalah penggunaan informasi akuntansi pada UKM. variabel independen merupakan variabel-variabel yang mengakibatkan adanya perubahan pada variabel yang terikat. Dalam penelitian ini variabel independen yang digunakan yaitu skala usaha, usia bisnis, pendidikan terakhir dan pelatihan akuntansi.

Skala pengukuran yang digunakan dalam penelitian ini untuk mengukur kelima variabel menggunakan skala Likert yang dirancang untuk menelaah seberapa kuat subjek menyetujui suatu pernyataan (Sekaran dan Bougie, 2017). Dalam penelitian ini menggunakan sumber data primer yang didapatkan langsung dari hasil kuesioner yang disebarkan kepada pemilik/manajer UKM dan menggunakan beberapa sumber literatur primer dimana kejadian pertama dari sebuah karya meliputi laporan, thesis, email, prosiding konferensi, laporan perusahaan, sumber naskah yang tidak diterbitkan, beberapa publikasi pemerintah (Saunders, et al., 2012). Teknik pengumpulan data yang digunakan untuk mengumpulkan data dalam penelitian ini yaitu survei menggunakan kuesioner yang disebarkan langsung kepada pemilik/manajer UKM di Kota Gresik secara acak. Responden diberikan waktu untuk mengisi kuesioner yang dibagikan dan akan dikumpulkan langsung oleh peneliti.

Menurut Chandrarin (2017: 139-141) terdapat empat langkah yang dibutuhkan dalam melakukan pengujian regresi linier berganda yaitu Hasil statistik deskriptif digunakan untuk memberikan gambaran umum tentang variabel-variabel yang ada. Statistik deskriptif menggambarkan data dari variabel yang digunakan dalam penelitian berdasarkan hasil dari data yang diolah, yaitu: nilai minimum, nilai maksimum, rata-rata (mean), median, dan standar deviasi. Analisis ini sangat membantu dalam meringkas perbandingan beberapa variabel data skala dalam satu tabel serta dapat digunakan melakukan pengamatan penyimpangan data (Trihendradi, 2009).

\section{Hasil Penelitian}

Adapun yang menjadi obyek dalam penelitian ini adalah UKM di Kabupaten Gresik. Dimana berdasarkan data dari pemerintah kabupaten Gresik yang terdapat pada situs resminya yaitu https://gresikkab.go.id/ukm/ terdapat $132 \mathrm{UKM}$ yang terdaftar secara resmi di pemerintah kota Gresik. Karena untuk pemenuhan sample yang cukup maka dipilihlah 100 UKM yang saya ketahui secara Jarak dan saya kenal UKM tersebut kemudian diberikan kuesioner dari 
tanggal 28 Agustus sampai dengan 13 September 2020 dari hasil pembagian 100 kuesioner UKM terpilih tersebut sejumlah 86 UKM yang bersedia mengisi kuesioner yang telah dibagikan secara langsung ke pemilik UMK di kota Gresik.

Untuk mengetahui tanggapan responden terhadap suatu variabel yang akan diteliti, digunakan nilai maksimum dan minimum. Skala penelitian ini menggunakan skala 1 sampai 5, maka nilai minimal dan maksimal dapat dikategorikan sebagai berikut:

$$
\begin{gathered}
\text { Range }=\frac{\text { Pengukuran Tertinggi }- \text { Pengukuran Terendah }}{\text { Jumlah Kategori }} \\
\text { Range }=\frac{5-1}{5} \\
\text { Range }=0,80
\end{gathered}
$$

Berdasarkan pada rumus di atas maka dapat diperoleh kriteria dari variabel yang disajikan pada Tabel sebagai berikut:

Tabel 1

\begin{tabular}{lll}
\multicolumn{3}{l}{ Interval Rata - Rata Skor } \\
\hline No & Range & Keterangan \\
\hline 1 & $1,00 \mathrm{~s} / \mathrm{d} 1,80$ & Sangat Rendah \\
\hline 2 & $1,81 \mathrm{~s} / \mathrm{d} 2,60$ & Rendah \\
\hline 3 & $2,61 \mathrm{~s} / \mathrm{d} 3,40$ & Netral \\
\hline 4 & $3,41 \mathrm{~s} / \mathrm{d} 4,20$ & Tinggi \\
\hline 5 & $4,21 \mathrm{~s} / \mathrm{d} 5,00$ & Sangat Tinggi \\
\hline
\end{tabular}

Sumber: Data penelitian, diolah.

Hasil tabel tersebut mengenai interval rata-rata skor selanjutnya akan digunakan untuk menginterpretasikan nilai mean (rata-rata) jawaban responden.

Tabel 2

Hasil Analisa Uji Reliabilitas

\begin{tabular}{llll}
\hline Variabel & Cronbach's Alpha & Syarat & Keterangan \\
\hline Skala Usaha & 0,760 & $>0,6$ & Reliabel \\
\hline Usia Bisnis & 0,808 & $>0,6$ & Reliabel \\
\hline Pengetahuan Akuntansi & 0,793 & $>0,6$ & Reliabel \\
\hline Pelatihan Akuntansi & 0,728 & $>0,6$ & Reliabel \\
\hline Penggunaan Informasi Akuntansi & 0,947 & $>0,6$ & Reliabel \\
\hline
\end{tabular}

Hasil pengolahan data di tabel tersebut menunjukkan hasil bahwa setiap variabel yang digunakan dalam penelitian ini yaitu skala usaha, usia bisnis, pengetahuan akuntansi, pelatihan akuntansi dan penggunaan informasi akuntansi menunjukkan hasil yang reliabel dengan hasil nilai Cronbach"s Alpha lebih besar dari 0,6. Hal ini menunjukkan bahwa setiap pernyataan yang digunakan dalam angket mampu memperoleh data yang konsisten.

\section{Pembahasan Penelitian}

Berikut adalah hasil pengolahaan data yang digunakan untuk membentuk persamaan regresi. Maka diperoleh persamaan regresi linear berganda dimana variabel terikatnya (Y) dihubungkan / dijelaskan oleh lebih dari satu variabel bebas $\left(\mathrm{X}_{1}, \mathrm{X}_{2}, \mathrm{X}_{3}, \mathrm{X}_{4}\right)$ namun masih menunjukkan hubungan yang linear dengan rumus sebagai berikut :

$Y=a+b_{1} X_{1}+b_{2} X_{2}+b_{3} X_{3}+b_{4} X_{4}+e$

Keterangan : 


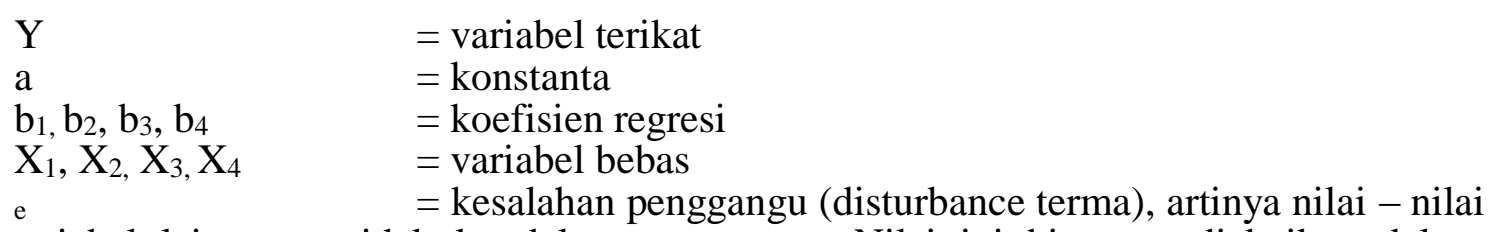
dari variabel lain yang tidak ke dalam persamaan. Nilai ini biasanya diabaikan dalam perhitungan.

Tabel 3

Persamaan Regresi

\begin{tabular}{|c|c|c|c|}
\hline \multirow[t]{2}{*}{ Model } & Standardized Coefficients & \multirow[t]{2}{*}{$\mathbf{t}$} & \multirow[t]{2}{*}{ Sig. } \\
\hline & Beta & & \\
\hline $1 \quad$ (Constant) & .210 & 1.194 & .236 \\
\hline Skala Usaha & 286 & 3.284 & .002 \\
\hline Usia Bisnis & 201 & 2.733 & .008 \\
\hline Pengetahuan Akuntansi & 240 & 3.248 & .002 \\
\hline Pelatihan Akuntansi & .297 & 3.705 & .000 \\
\hline
\end{tabular}

Berdasarkan hasil perhitungan diatas maka yang signfikan adalah sebagai berikut:

$\mathrm{Y}=0,210+0,286 \mathrm{X}_{1}+0,201 \mathrm{X}_{2}+0,240 \mathrm{X}_{3}+0,297 \mathrm{X}_{4}+\mathrm{e}$

Pada variabel penelitian skala usaha $\left(\mathrm{X}_{1}\right)$ hasil menunjukkan nilai koefisien regresi yang positif. Berati hubungan variabel skala usaha $\left(\mathrm{X}_{1}\right)$ searah dengan penggunaan informasi akuntansi (Y) dengan nilai sebesar 0,286, dengan asumsi apabila nilai skala usaha sendiri meningkat maka nilai penggunaan informasi akuntansi juga meningkat sebesar 0,286.

Pada variabel penelitian usia bisnis $\left(\mathrm{X}_{2}\right)$ hasil menunjukkan nilai koefisien regresi yang positif. Berati hubungan variabel usia bisnis $\left(\mathrm{X}_{2}\right)$ searah dengan penggunaan informasi akuntansi (Y) dengan nilai sebesar 0,201, dengan asumsi apabila nilai usia bisnis sendiri meningkat maka nilai penggunaan informasi akuntansi juga meningkat sebesar 0,201.

Pada variabel penelitian pengetahuan akuntansi $\left(\mathrm{X}_{3}\right)$ hasil menunjukkan nilai koefisien regresi yang positif. Berati hubungan variabel pengetahuan akuntansi $\left(\mathrm{X}_{3}\right)$ searah dengan penggunaan informasi akuntansi (Y) dengan nilai sebesar 0,240, dengan asumsi apabila nilai pengetahuan akuntansi sendiri meningkat maka nilai penggunaan informasi akuntansi juga meningkat sebesar 0,240 .

Pada variabel penelitian pelatihan akuntansi $\left(\mathrm{X}_{4}\right)$ hasil menunjukkan nilai koefisien regresi yang positif. Berati hubungan variabel pelatihan akuntansi $\left(\mathrm{X}_{4}\right)$ searah dengan penggunaan informasi akuntansi (Y) dengan nilai sebesar 0,297, dengan asumsi apabila nilai pelatihan akuntansi sendiri meningkat maka nilai penggunaan informasi akuntansi juga meningkat sebesar 0,297.

Hasil pengujian dapat dilihat pada tabel 1 . Berdasarkan hasil perhitungan dari uji t dari tabel ini maka dapat diketahui hasil pengujian variabelnya sebagai berikut:

a. Pengaruh skala usaha terhadap penggunaan informasi akuntansi

Berdasarkan hasil perhitungan, diperoleh nilai $t$-value variabel skala usaha memiliki nilai sebesar 3,284 yang mana lebih besar daripada t-statistik 1,98, serta nilai signifikansi variabel skala usaha sendiri bernilai 0,002 yang mana lebih kecil daripada 0,05 . Hal ini menandakan bahwa skala usaha mempuyai pengaruh signifikan terhadap penggunaan informasi akuntansi. Maka pernyataan $\mathrm{H}_{1}$ tentang dugaan skala usaha berpengaruh positif dan signifikan terhadap penggunaan informasi akuntansi diterima.

b. Pengaruh usia bisnis terhadap penggunaan informasi akuntansi

Berdasarkan hasil perhitungan, diperoleh nilai $t$-value variabel usia bisnis memiliki nilai sebesar 2,733 yang mana lebih besar daripada $t$-statistik 1,98 , serta nilai signifikansi variabel usia bisnis sendiri bernilai 0,008 yang mana lebih kecil daripada 0,05 . Hal ini menandakan bahwa usia bisnis mempuyai pengaruh signifikan terhadap penggunaan informasi akuntansi. Maka pernyataan $\mathrm{H}_{2}$ tentang dugaan usia bisnis berpengaruh positif dan signifikan terhadap penggunaan informasi akuntansi diterima.

c. Pengaruh pengetahuan akuntansi terhadap penggunaan informasi akuntansi 
Berdasarkan hasil perhitungan, diperoleh nilai t-value variabel pengetahuan akuntansi memiliki nilai sebesar 3,248 yang mana lebih besar daripada $t$-statistik 1,98 , serta nilai signifikansi variabel pengetahuan akuntansi sendiri bernilai 0,002 yang mana lebih kecil daripada 0,05. Hal ini menandakan bahwa pengetahuan akuntansi mempuyai pengaruh signifikan terhadap penggunaan informasi akuntansi. Maka pernyataan $\mathrm{H}_{3}$ tentang dugaan pengetahuan akuntansi berpengaruh positif dan signifikan terhadap penggunaan informasi akuntansi diterima.

d. Pengaruh pelatihan akuntansi terhadap penggunaan informasi akuntansi

Berdasarkan hasil perhitungan, diperoleh nilai $t$-value variabel pelatihan akuntansi memiliki nilai sebesar 3,705 yang mana lebih besar daripada $t$-statistik 1,98 , serta nilai signifikansi variabel pelatihan akuntansi sendiri bernilai 0,000 yang mana lebih kecil daripada 0,05 . Hal ini menandakan bahwa pelatihan akuntansi mempuyai pengaruh signifikan terhadap penggunaan informasi akuntansi. Maka pernyataan $\mathrm{H}_{4}$ tentang dugaan pelatihan akuntansi berpengaruh positif dan signifikan terhadap penggunaan informasi akuntansi diterima.

Koefisien korelasi parsial digunakan untuk melihat seberapa besar hubungan antara variabel bebas terhadap variabel terikat dalam suatu penelitian secara individual. Berikut merupakan hasil koefisien korelasi parsial dalam penelitian ini:

Tabel 4

\section{Uji Koefisien Korelasi Parsial}

\begin{tabular}{|c|c|c|c|c|}
\hline \multicolumn{5}{|c|}{ Coefficients $^{\mathrm{a}}$} \\
\hline & \multicolumn{3}{|l|}{ Correlations } \\
\hline & & Zero-order & Partial & Part \\
\hline \multirow[t]{5}{*}{1} & Todel & & \multirow{2}{*}{213} & 101 \\
\hline & Skala Usaha & .859 & & .141 \\
\hline & Usia Bisnis & .802 & .291 & .117 \\
\hline & Pengetahuan Akuntansi & .807 & .340 & .139 \\
\hline & Pelatihan Akuntansi & .843 & .381 & .159 \\
\hline
\end{tabular}

a. Dependent Variable: Penggunaan Informasi Akuntansi

Sumber: lampiran 7

Berdasarkan tabel tersebut dapat dilihat bahwa nilai koefisien korelasi parsial untuk variabel skala usaha adalah sebesar 0,343, hal ini berarti skala usaha memiliki hubungan yang lemah terhadap penggunaan informasi akuntansi. Nilai koefisien korelasi parsial untuk variabel usia bisnis adalah sebesar 0,291, hal ini berarti usia bisnis memiliki hubungan yang lemah terhadap penggunaan informasi akuntansi. Nilai koefisien korelasi parsial untuk variabel pengetahuan akuntansi adalah sebesar 0,340 , hal ini berarti pengetahuan akuntansi memiliki hubungan yang lemah terhadap penggunaan informasi akuntansi. Nilai koefisien korelasi parsial untuk variabel pelatihan akuntansi adalah sebesar 0,381, hal ini berarti pelatihan akuntansi memiliki hubungan yang lemah terhadap penggunaan informasi akuntansi. Selain itu juga dapat dilihat bahwa nilai koefisien korelasi paling besar terdapat pada variabel pelatihan akuntansi, diikuti oleh variabel skala usaha, pengetahuan akuntansi dan paling kecil adalah pada variabel usia bisnis. Hal ini berarti variabel yang paling memberikan pengaruh dominan pada penggunaan informasi akuntansi adalah variabel pelatihan akuntansi diikuti oleh variabel skala usaha dan juga variabel pelatihan akuntansi serta yang paling kecil pengaruhnya pada penggunaan informasi akuntansi adalah variabel usia bisnis.

\subsubsection{Pengaruh Skala Usaha terhadap Penggunaan Informasi Akuntansi}

Berdasarkan pengujian hipotesis pertama pada uji t dapat diterima dengan hasil $t$-value pada variabel skala usaha $\left(\mathrm{X}_{1}\right)$ bernilai 3,284 dan hasil tersebut lebih besar dari nilai t-statisik sebesar 1,968, selain itu juga nilai signikansi sebesar 0,002 lebih kecil daripada nilai alpha sebesar 0,05. Hal tersebut menunjukkan bahwa terdapat pengaruh parsial pada variabel dependen skala usaha $\left(\mathrm{X}_{1}\right)$ terhadap variabel independen pengguna informasi akuntansi $(\mathrm{Y})$. 
Hasil pengujian mendukung hipotesis pertama penelitian yaitu "skala usaha berpengaruh positif dan signifikan terhadap pengguna informasi akuntansi" yang berarti semakin besar skala usaha maka semakin tinggi kemungkinan pemilik UKM di Gresik untuk menggunakan informasi akuntansi.

Hasil penelitian ini mendukung penelitian yang dilakukan oleh Sitoremi dan Fuad (2013) yang menemukan bahwa ukuran usaha berpengaruh signifikan terhadap penggunaan informasi akuntansi. Penelitian lain dari Nirwana dan Purnama (2019) juga mendukung hasil penelitian ini sebab dalam penelitian tersebut ditemukan bahwa skala usaha berpengaruh positif dan signifikan terhadap penggunaan informasi akuntansi. Hasil peneltian Pasaribu (2018) juga memperkuat dukuangan tarhadap hasil penelitian ini dimana ditemukan bahwa skala usaha berpengaruh terhadap penggunaan informasi akuntansi.

Meski demikian hasil penelitian ini juga mendapatkan hasil yang berbeda dibandingkan dengan hasil penelitian terdahulu yang dilakukan oleh Andriani dan Zuliyati (2015) yang menyatakan bahwa skala usaha berpengaruh tidak signifikan terhadap informasi akuntansi. Selain itu penelitian Keristin (2018) juga memiliki hasil yang berbeda dari hasil penelitian ini dimana skala usaha ditemukan secara parsial berpengaruh positif dan tidak singnifikan terhadap penggunaan informasi akuntansi. Penelitian lain dari Rikah, Alliyah, dan Adib (2018) juga memiliki perbedaan dengan hasil penelitian saat ini dimana skala usaha ditemukan berpengaruh tidak signifikan terhadap informasi akuntansi.

4.2.2 Pengaruh Usia Bisnis terhadap Penggunaan Informasi Akuntansi

Berdasarkan pengujian hipotesis kedua pada uji t dapat diterima dengan hasil t-value pada variabel usia bisnis $\left(\mathrm{X}_{2}\right)$ bernilai 2,733 dan hasil tersebut lebih besar dari nilai t-statisik sebesar 1,968, selain itu juga nilai signikansi sebesar 0,008 lebih kecil daripada nilai alpha sebesar 0,05. Hal tersebut menunjukkan bahwa terdapat pengaruh parsial pada variabel dependen usia bisnis $\left(\mathrm{X}_{2}\right)$ terhadap variabel independen pengguna informasi akuntansi $(\mathrm{Y})$. Hasil pengujian mendukung hipotesis kedua penelitian yaitu "usia bisnis berpengaruh positif dan signifikan terhadap pengguna informasi akuntansi" yang berarti semakin lama usia bisnis maka semakin tinggi kemungkinan pemilik UKM di Gresik untuk menggunakan informasi akuntansi.

Hasil penelitian ini mendukung penelitian yang dilakukan oleh Andriani dan Zuliyati (2015) yang menemukan bahwa usia bisnis terhadap informasi akuntansi. Penelitian lain dari (Linear Diah Sitoresmi, 2013) juga mendukung hasil penelitian ini sebab dalam penelitian tersebut ditemukan bahwa usia usaha secara signifikan berpengaruh pada penggunaan informasi akuntansi. Hasil peneltian Rikah, Alliyah, dan Adib (2018) juga memperkuat dukuangan tarhadap hasil penelitian ini dimana ditemukan bahwa usia bisnis berpengaruh positif terhadap informasi akuntansi.

Meski demikian hasil penelitian ini juga mendapatkan hasil yang berbeda dibandingkan dengan hasil penelitian terdahulu yang dilakukan oleh Keristin (2018) yang menyatakan bahwa usia bisnis secara parsial berpengaruh negatif dan tidak signifikan. Selain itu penelitian Novianti, Mustika, dan Eka, (2018) juga memiliki hasil yang berbeda dari hasil penelitian ini dimana umur usaha tidak berpengaruh terhadap penggunaan informasi akuntansi. Penelitian lain dari (Hadi et al., 2013) juga memiliki perbedaan dengan hasil penelitian saat ini dimana umur usaha secara mandiri berpengaruh negatif terhadap penggunaan informasi akuntansi.

\subsubsection{Pengaruh Pengetahuan Akuntansi terhadap Penggunaan Informasi Akuntansi}

Berdasarkan pengujian hipotesis ketiga pada uji t dapat diterima dengan hasil $t$-value pada variabel pengetahuan akuntansi $\left(\mathrm{X}_{3}\right)$ bernilai 3,248 dan hasil tersebut lebih besar dari nilai tstatisik sebesar 1,968, selain itu juga nilai signikansi sebesar 0,002 lebih kecil daripada nilai alpha sebesar 0,05 . Hal tersebut menunjukkan bahwa terdapat pengaruh parsial pada variabel dependen pengetahuan akuntansi $\left(\mathrm{X}_{3}\right)$ terhadap variabel independen pengguna informasi akuntansi (Y). Hasil pengujian mendukung hipotesis ketiga penelitian yaitu "pengetahuan akuntansi berpengaruh positif dan signifikan terhadap pengguna informasi akuntansi" yang berarti semakin baik pengetahuan akuntansi yang dimiliki maka semakin tinggi kemungkinan pemilik UKM di Gresik untuk menggunakan informasi akuntansi.

Hasil penelitian ini mendukung penelitian yang dilakukan oleh (Nafsiah, 2019) yang menemukan bahwa pengetahuan akuntansi ditemukan berpengaruh signifikan terhadap penggunaan informasi akuntansi pada UKM. Penelitian lain dari Fitriyah (2006) dan Ismail 
dan King (2007) yang menunjukkan bahwa pengetahuan akuntansi pemilik/pengelola memiliki efek positif pada penerapan informasi akuntansi. Hasil peneltian Kiryanto, et al. (2001) dan Widiyanti (2013) juga mendukung hasil penelitian sebelumnya, menunjukkan bahwa pengetahuan akuntansi memiliki efek positif pada penggunaan informasi akuntansi keuangan. Meski demikian hasil penelitian ini juga mendapatkan hasil yang berbeda dibandingkan dengan hasil penelitian terdahulu yang dilakukan oleh Puspita dan Pramono (2019) yang menyatakan bahwa pengetahuan akuntansi tidak berpengaruh signifikan terhadap penggunaan informasi akuntansi.

\subsubsection{Pengaruh Pelatihan Akuntansi terhadap Penggunaan Informasi Akuntansi}

Berdasarkan pengujian hipotesis keempat pada uji t dapat diterima dengan hasil $t$-value pada variabel pelatihan akuntansi $\left(\mathrm{X}_{4}\right)$ bernilai 3,705 dan hasil tersebut lebih besar dari nilai tstatisik sebesar 1,968, selain itu juga nilai signikansi sebesar 0,000 lebih kecil daripada nilai alpha sebesar 0,05. Hal tersebut menunjukkan bahwa terdapat pengaruh parsial pada variabel dependen pelatihan akuntansi $\left(\mathrm{X}_{4}\right)$ terhadap variabel independen pengguna informasi akuntansi (Y). Hasil pengujian mendukung hipotesis keempat penelitian yaitu "pelatihan akuntansi berpengaruh positif dan signifikan terhadap pengguna informasi akuntansi" yang berarti semakin baik pelatihan akuntansi yang didapat maka semakin tinggi kemungkinan pemilik UKM di Gresik untuk menggunakan informasi akuntansi.

Hasil penelitian ini mendukung penelitian yang dilakukan oleh (Nafsiah, 2019) yang menemukan bahwa pelatihan akuntansi berpengaruh signifikan terhadap penggunaan informasi akuntansi. Penelitian lain dari (Asrida, 2019) yang menunjukkan bahwa pelatihan akuntansi berpengaruh signifikan terhadap penggunaan informasi akuntansi. Hasil peneltian (Studi et al., 2015) juga mendukung hasil penelitian sebelumnya, menunjukkan bahwa pelatihan akuntansi berpengaruh signifikan terhadap penggunaan informasi akuntansi. Meski demikian hasil penelitian ini juga mendapatkan hasil yang berbeda dibandingkan dengan hasil penelitian terdahulu yang dilakukan oleh Santosa (2019) yang menyatakan bahwa pelatihan akuntansi tidak berpengaruh signifikan terhadap penggunaan informasi akuntansi.

\section{Simpulan}

Kesimpulan dari hasil penelitian ini memberikan bukti baru bahwa kemauan pemilik UKM di kota Pudak Gresik untuk menggunakan informasi akuntansi dapat dipengaruhi oleh skala usaha, usia bisnis, pengetahuan akuntansi serta pelatihan akuntansi. Hasil ini diharapkan bisa dijadikan dasar atau acuan bagi pihak-pihak yang terkait dengan penggunaan informasi akuntansi. Sebab dengan meningkatnya skala usaha suatu UKM maka kebutuhan akan informasi akuntansi yang digunakan untuk membuat keputusan manajerial untuk UKM menjadi sangat penting untuk kelangsungan hidup sebuah UKM. Selanjutnya berkaitan dengan usia bisnis UKM itu sendiri, dimana semakin lama bisnis beroperasi, kebutuhan informasi akan lebih kompleks sehingga meningkatkan kesadaran pemilik UKM pentingnya akuntansi untuk terus mempertahankan bisnis mereka dan untuk tumbuh. Terkait dengan pengetahuan akuntansi juga memiliki dampak pada penggunaan informasi akuntansi pada UKM sebab proses belajar tentang akuntansi akan meningkatkan pengetahuan akuntansi manajer/pemilik bisnis (pengusaha), sehingga pemahaman pengusaha (manajer) untuk menerapkan informasi akuntansi juga akan meningkat. Terakhir mengenai pelatihan akuntansi, dimana pelatihan seputar akuntansi yang telah diikuti oleh manajer atau pemilik usaha dapat membuat praktek menggunakan informasi akuntansi menjadi lebih besar, karena mereka tahu lebih banyak tentang pengetahuan akuntansi daripada manajer atau pemilik bisnis yang tidak pernah mengikuti pelatihan akuntansi.

Adapun saran yang dapat diberikan penulis untuk memperbaiki tesis ini antara lain adalah agar memperbesar jumlah sampel dan melengkapi metoda survai dengan wawancara karena saat melakukan penelitian ini peneliti sempat mewawancarai beberapa responden dan menemukan adanya perbedaan antara jawaban di kuesioner dan jawaban secara lisan untuk pertanyaan/pernyataan yang sama. Memperbaiki terlebih dahulu kuesioner yang digunakan dalam penelitian ini atau menggunakan kuesioner yang tingkat validitas dan reliabilitasnya lebih tinggi. Mempertimbangkan variabel-variabel lain yang diduga berpengaruh terhadap penggunaan informasi akuntansi, misalnya masa memimpin binis atau usaha, ketaatan terhadap undang-undaan, serta omzet usaha. 
Terdapat beberapa keterbatasan yang dirasakan oleh peneliti dalam penulisan penelitian ini, antara lain adalah objek penelitian yang hanya menggunakan ukm pada suatu daerah saja yaitu di kota pudak Gresik menjadikan hasil penelitian ini kurang dapat memberikan gambaran secara umum jika penelitian ini dilakukan di wilayah lain. Kurangnya pemahaman dari responden terhadap pertanyaan-pertanyaan dalam kuisioner serta sikap kepedulian dan keseriusan dalam menjawab semua pertanyaan-pertanyaan yang ada. Masalah subjektivitas dari responden dapat mengakibatkan hasil penelitian ini rentan terhadap biasnya jawaban responden. Keterbatasan yang dirasa cukup mengganggu dalam penelitian ini adalah variabel-variabel yang digunakan sebagai variabel independen dirasakan masih terlalu sedikit. Karena hanya membahas tentang skala usaha, usia bisnis, pengetahuan akuntansi serta pelatihan akuntansi padahal berdasarkan hasil penelitian terdahulu mengenai faktorfaktor yang mempengaruhi penggunaan informasi akuntansi masih terdapat variabel-variabel lain yang ditemukan berpengaruh seperti masa memimpin perusahaan (Hendrawati, 2017) (Andriani dan Zuliyati, 2015, ketaatan terhadap undang undang dan peraturan pemerintah (Keristin, 2018), serta omzet usaha (Fitriani, Sukesti dan Sristiana, 2019).

\section{Daftar Pustaka}

Andriani, N., dan Zuliyati., (2015). Faktor-Faktor Yang Mempengaruhi Penggunaan Informasi Akuntansi (Studi Pada UMKM Kain Tenun Ikat Troso Jepara). Prosiding Seminar Kebangkitan Teknologi Tahun 2015, Universitas Muria Kudus.

Asrida, P. D., (2018). The Impact of Accounting Knowledge and Training towards The Use of Accounting Information on The Owners of MSME in Badung. Advances in Economics, Business and Management Research, Vol. 69, pp. 145-154.

Aufar, A., (2013). Faktor-faktor Yang Mempengaruhi Penggunaan Informasi Akuntansi Pada UMKM (Survei Pada Perusahaan Rekanan PT.PLN (Persero) di Kota Bandung). Skripsi. Fakultas Ekonomi Universitas Widyatama.

Belkaoui, A. R., (2011). Accounting Theory. Jakarta: Salemba Empat.

Budiyanto, H. (2014). Analisis Faktor-faktor yang Mempengaruhi Penggunaan Informasi Akuntansi pada Perusahaan Tenun Troso Jepara. Skripsi, Universitas Islam Nahdatul Ulama.

Chandrarin, G., (2017). Metode Riset Akuntansi Pendekatan Kuantitatif, Jakarta: Salemba Empat.

Djazari, M., dan Sagoro, E. M., (2011). Evaluasi prestasi belajar mahasiswa program kelanjutan studi jurusan pendidikan akuntansi ditinjau dari IPK D3 dan asal perguruan tinggi, Jurnal Pendidikan Akuntansi Indonesia, Vol. 9, No. 2, pp. 103112.

Fitriyah, H., (2006). Analisis Faktor-Faktor yang Mempengaruhi Penggunaan Informasi Akuntansi Pada Usaha Surabaya: Tesis Program Pasca Sarjana Universitas.

Frima, R., dan Surya, F., (2018). Pengaruh Tingkat Pendidikan dan Penggunaan Informasi Akuntansi Manajemen Terhadap Kinerja UKM di Kota Padang. Jurnal Akuntansi \& Manajemen, Vol. 13, No. 1, pp. 93-111.

Ghozali, I. (2013). Aplikasi Analisis Multivariate dengan Program IBM SPSS. 21 Update PLS Regresi. Semarang: Badan Penerbit Universitas Diponegoro.

Hadi, A. P., Putri, N. K., dan Faturokhman, A., (2019). Faktor-Faktor Yang Mempengaruhi Penggunaan Informasi Akuntansi Pada Usaha Kecil Dan Menengah. Akuntabel, Vol. 16, No. 2, pp. 165-171.

Hartono, W., (2013). UMKM: Pencatatan Transaksi. Universitas Kristen Satya Wacana.

Hermawan, F., (2010). Penerapan Akuntansi Pada Usaha Kecil (Studi Kasus Perusahaan Kecil Di Magelang). Universitas Kristen Satya Wacana.

Holmes, S., dan Nicholls., (1988). An Analysis Of The Use Of Accounting Information by Australian Small Business. Journal of small business management, Vol. 26, No. 20 , pp. $57-68$

Ismail, N. A., and King, M., (2007). Factors Influencing the Alignment of Accounting Information Systems in Small and Medium Sized Malaysian Manufacturing Firms, Journal of Information Systems and Small Business, Vol. 1, No. 1-2, pp: 1-19 
Jones, K. H., Price, J. B., Werner, M. L., dan Doran, M. S., (1996). Introduction To Financial Accounting: A User Perspective. Upper Saddle. New Jersey: Prentice Hall.

Karyawati, G., (2008). Akuntansi Usaha Kecil Untuk Berkembang. Jakarta: PT Raja Grafindo Persada.

Kurniawati, E. P., Kurniawan, E. Y., dan Kristiani, M., (2013). Accounting information for business decision making and performance assessment in small and medium enterprises (SMEs), The Journal of Social Science, Vol. 76, pp. 67-95.

Kurniawati, E. P., Nugroho, P. I., dan Setiawati, D., (2011). Penerapan akuntansi usaha kecil menengah (UKM): studi kasus pada usaha dagang kota salatiga, in Management The Next Opportunity and Challenge From Competitiion To Collaboration. Bandung, pp. 23-136.

Mubarok, A., (2011). Pengaruh faktor tingkat pendidikan, pengalaman memimpin dan skala usaha terhadap penerapan sistem informasi akuntansi (penelitian pada lembaga keuangan mikro syariah "BMT" di daerah Tegal), Jurnal SOSEKHUM, Vol. 7, No. 10, pp. 1-17.

Murniati., (2002). Analisis Faktor-Faktor Yang Mempenaruhi Penyiapan Dan Penggunaan Informasi Akuntansi Pada Pengusaha Kecil Dan Menengah Di Jawa Tengah. Tesis Universitas Diponegoro Semarang.

Nafsiah, S. N., dan Birahma, R. Y., (2019). Faktor-Faktor Yang Mempengaruhi Penggunaan Informasi Akuntansi Pada UKM (Survei Perusahaan UKM Pdam Tirta Sejiran Setason Kab. Bangka Barat). MBIA, Vol. 18, No. 3, pp. 90-100.

Nirwana, A., dan Purnama, D., (2019). Pengaruh Jenjang Pendidikan, Skala Usaha Dan Lama Usaha Terhadap Penggunaan Informasi Akuntansi Pada UKM Di Kecamatan Ciawigebang. JRKA, Vol. 5, No. 4, pp. 55-65.

Priyanto, D., (2014). SPSS 22 Pengolahan Data Terpraktis. Yogyakarta : CV. Andi Offset.

Puspita, M. E., dan Pramono, J., (2019). Factors affecting the use of accounting information in small and medium enterprises (SMEs): a study on SMEs in Tingkir, Salatiga. The Indonesian Accounting Review Vol. 9, No. 2, pp. 207-225.

Ratnasari, A. R., (2014). Faktor-Faktor Yang Mempengaruhi Penggunaan Informasi Akuntansi Bagi Usaha Mikro Kecil Menengah (Binaan Dinas Koperasi Dan UMKM Kota Kediri). Skripsi. Fakultas Bisnis Universitas Negeri Semarang.

Riduwan dan Sunarto. (2014). Pengantar Statistika Untuk Penelitian: Pendidikan,. Sosial, Komunikasi, Ekonomi, dan Bisnis. Bandung: Alfabeta.

Rikah, A. S., dan Adib, M. S., (2018). Faktor-Faktor Yang Mempengaruhi Penggunaan Informasi Akuntansi Pada Usaha Kecil Menengah Kabupaten Rembang. Seminar Nasional Hasil Penelitian (SNHP)-Vii Lembaga Penelitian Dan Pengabdian Kepada Masyarakat Universitas Pgri Semarang Semarang, 26 Oktober 2017.

Santosa, I. M. E. S., dan Wulandari, P. R., (2019). Accounting Information of Micro, Small, Medium Enterprise in Gianyar, Regency. IJSEGCE, Vol. 2, No. 3, pp. 368-376.

Sari, D. P., (2013). Analisis faktor-faktor yang mempengaruhi penyediaan dan penggunaan informasi akuntansi pada UKM di Kecamatan Rumbai Pesisir. Universitas Riau.

Sari, M. J., (2011). Penerapan Pencatatan Keuangan Pada Industri Kecil Rumahan (Studi Kasus pada Pengusaha Laundry Kiloan "De Clean Priority" di Surabaya). Undergraduate thesis, Faculty of Economics.

Saunders, M., Lewis, P., dan Thornhill, A., (2012). Research Methods for Business Students. Harlow: Pearson Education Ltd.

Sekaran, U., dan Bougie, R., (2017). Metode Penelitian untuk Bisnis: Pendekatan Pengembangan-Keahlian, Edisi 6, Buku 2, Jakarta: Salemba Empat.

Setiawati, D., (2010). Penerapan akuntansi untuk Usaha Kecil Menengah (UKM) : studi kasus di usaha dagang Kota Salatiga. Universitas Kristen Satya Wacana.

Setyowati, D., (2011). Faktor-Faktor Yang Mempengaruhi Persepsi Pengusaha Kecil Dan Menengah Atas Informasi Akuntansi. Skripsi. Program Studi Akuntansi Fakultas Ekonomi Universitas Negeri Semarang, Jawa Tengah.

Sitoresmi, L. D., dan Fuad., (2013). Faktor-Faktor Yang Mempengaruhi Penggunaan Informasi Akuntansi Pada Usaha Kecil Dan Menengah (Studi Pada Kub Sido Rukun Semarang). Diponegoro Journal Of Accounting, Vol. 2, No. 3, pp. 1-13.

Sujarweni, V. W., (2015). Metodologi Penelitian Bisnis \& Ekonomi. Yogyakarta: Pustaka Baru Press. 
Trihendradi. C., (2009). Step by Step SPSS 16 Analisis Data Statistik. Yogyakarta : CV. Andi Offset.

Tuti, R., (2015). Faktor-Faktor Yang Memepengaruhi Pemahaman UMKM Dalam Menyusun Laporan Keuangan Berdasarkan SAK ETAP. Skripsi. Fakultas Bisnis Universitas Katolik Widya Mandala Surabaya.

Wahyudi, M., (2009). Analisis Faktor-Faktor yang Mempengaruhi Penggunaan Informasi Akuntansi Pada Usaha Kecil dan Menengah (UKM) di Yogyakarta. Tesis. Fakultas Ekonomi Universitas Diponegoro Semarang.

Widiyanti, M., (2013). Analisis Faktor-Faktor Yang Mempengaruhi Persepsi Pengusaha Kecil dan Menengah atas Penggunaan Informasi Akuntansi. Skripsi, Universitas Negeri Semarang. 